\title{
NILAI FILOSOFIS DAN SPIRITUAL DALAM TRADISI BAUMO MASYARAKAT KECAMATAN BATIN XXIV KABUPATEN BATANGHARI
}

\author{
Ziman \\ UIN Sulthan Thaha Saifuddin Jambi \\ Email: ziman1020@gmail.com
}

\begin{abstract}
This study discusses the philosophical and spiritual values contained in the baumo tradition of the people of Batin XXIV district, Batanghari Regency. The baumo tradition that has been going on for generations in the modern era is starting to be displaced by modern agricultural culture. Not only its existence has begun to be eroded by modern culture, but also the values contained therein have begun to be forgotten by the local community. Even though the baumo traditional values contain local wisdom values, environmental conservation values, spiritual values, and wisdom values that are very relevant in today's modern life. The method that I use in this research is a qualitative research method, to explore and understand the social and cultural phenomena that exist in society. The data collection method that the writer uses is through direct observation into the field, interviews with Umo farmers, community leaders, and traditional leaders, and documentation by examining documents related to the object of research, including Jambi Malay cultural texts. The results of this study indicate that: First, epistemologically, the community's knowledge in carrying out the baumo tradition is based on Jambi's traditional law and Malay culture, namely the syara' jointed tradition and the syara' with the Kitabullah jointed. Apart from that, the baumo tradition is also based on empirical knowledge or people's experiences in terms of natural phenomena. Axiologically, the baumo tradition contains environmental and ethical values in living life. Meanwhile, the baumo tradition also contains spiritual values in the form of belief in the soul of rice, basokat after harvesting umo as a form of belief in religion, and ethics in treating rice as a form of belief in the existence of God.
\end{abstract}

Keywords: Philosophical, Spiritual, Tradition, Baumo

\begin{abstract}
Abstrak
Penelitian ini membahas tentang nilai filosofis dan nilai spiritual yang terkandung dalam tradisi baumo masyarakat Kecamatan Batin XXIV
\end{abstract}


Kabupaten Batanghari. Tradisi baumo yang telah berlangsung secara turun temurun itu di era modern saat ini mulai tergeser eksistensinya oleh budaya pertanian modern. Tidak hanya eksistensinya saja yang mulai tergerus budaya modern, tetapi juga nilai-nilai yang terkandung di dalamnya pun mulai dilupakan masyarakat setempat. Padahal pada nilainilai tradisi baumo tersebut terkandung nilai kearifan lokal, nilai konservasi lingkungan, nilai spiritual dan nilai kearifan yang sangat relevan dalam kehidupan modern saat ini. Metode yang penulis gunakan dalam penelitian ini adalah metode penelitian kualitatif, dengan tujuan untuk menggali dan memahami fenomena sosial dan budaya yang ada di masyarakat. Adapun metode pengumpulan data yang penulis gunakan adalah melalui observasi langsung ke lapangan, wawancara kepada para petani umo, tokoh masyarakat dan tokoh adat, serta dokumentasi dengan meneliti dokumen-dokumen yang berkaitan dengan objek penelitian, termasuk naskah-naskah budaya melayu Jambi. Hasil dari penelitian ini menunjukan bahwa: Pertama, secara epistemologis pengetahuan masyarakat dalam melakukan tradisi baumo didasarkan pada hukum adat dan budaya melayu Jambi, yaitu adat yang bersendi syara', dan syara' yang bersendi kitabullah. Selain itu, tradisi baumo juga didasarkan pada pengetahuan empiris atau pengalaman masyarakat dalam hal gejala-gejala alam. Secara aksiologis, dalam tradisi baumo terkandung nilai etika lingkungan dan etika dalam menjalani hidup. Sementara itu, tradisi baumo juga mengandung nilai-nilai spiritual berupa keyakinan pada adanya jiwa padi, basokat saat usai memanen umo sebagai wujud keyakinan pada agama, serta adab dalam memperlakukan padi sebagai bentuk keyakinan pada adanya Tuhan.

Kata Kunci: Filosofis, Spiritual, Tradisi, Baumo

\section{Pendahuluan}

Indonesia sebagai negara yang kondisi wilayahnya geografis terpisah-pisah yang dapat melahirkan banyak suku, ras, etnis dan budaya yang berbeda di Indonesia, sehinga menjadikan bangsa yang multikultural. Karena masyarakat yang tinggal di setiap daerah pasti akan membentuk suatu kebudayaan atau tradisinya masingmasing. Menurut Nur Syam, budaya atau tradisi biasanya adalah sebagai sebuah kebiasaan yang telah diwariskan dari satu generasi ke generasi selanjutnya secara turun-temurun, karena tradisi 
mencakup berbagai nilai budaya yang meliputi adat istiadat, sistem kepercayaan, dan sebagainya. ${ }^{1}$

Jadi, dapat diartikan tradisi merupakan warisan masa lampau yang akan diteruskan oleh masa sekarang, yang berupa kebiasaan dan perilaku masyarakat setempat. Kemudian tradisi erat kaitannya dengan kehidupan masyarakat pedesaan, karena tradisi membentuk rasa kebersamaan. Hal ini sesuai dengan yang telah disebutkan dalam al-Qur'an surat al-A'raf: 199.

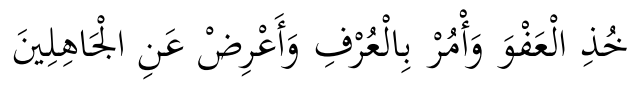

Jadilah engkau pemaaf dan surublah orang mengerjakan yang ma'ruf (tradisi yang baik), serta berpalinglah daripada orang-orang yang bodoh. ${ }^{2}$

Artinya, ayat di atas sebagai sebuah perintah dari Allah untuk mengerjakan yang ma'ruf bagi umat Islam. Jadi, maksud dari kata 'urf dalam ayat di atas dapat disebut dengan sebuah tradisi atau kebiasaan yang baik yang harus dan terus menerus dilakukan. Jadi, maksud ayat dapat disimpulkan bahwa mengerjakan perbuatan yang baik dalam kelompok masyarakat sudah menjadi keharusan baginya secara terus menerus. Sehingga menjadi sebuah tradisi yang dapat membentuk suatu karakter, sikap dan perilaku dalam menghadapi berbagai persoalan kehidupan mereka.

Menurut Hardjosoemantri, corak dalam alam pikiran masa lampau atau tradisional dalam masyarakat adat, pada umumnya berdasarkan pada cara pandang dan cara berpikirnya yang bersifat kosmis dan komunal. Berpikir kosmis ini, didasarkan pada anggapan bahwa kehidupan manusia seharus sesuai dan mengikuti alur tata alam semesta, karena manusia merupakan bagian yang tidak terpisahkan dan harus terintegrasi dalam kosmos itu sendiri. Sehingga ketertiban masyarakat sebenarnya tidak bisa terlepas dari

${ }^{1}$ Nur Syam, Islam Pesisir (Yogyakarta: Lkis Pelangi Aksara, 2015), 16-18.

${ }^{2}$ Q.S. Al-A'raf / 7:199

190| TAJDID vol. 19, No. 2, Juli - Desember 2020 
tata tertib alam semesta. ${ }^{3}$ Sedangkan berpikir komunal, yaitu berpikir masyarakat yang tradisional dengan melihat bahwa manusia merupakan bagian spesies yang keberadaannya tidak terlepas dari kelompoknya di mana ia bisa bersama-sama menyelenggarakan kehidupan mereka. Artinya, secara kodrati kehidupan manusia satu dengan lainnya tidak dapat dilepas satu dengan lainya, sehingga timbul sebuah konsekuensi untuk mempertahankan eksistensi budaya dan tradisinya secara bersamasama, termasuk dalam berhubungan dengan alam di sekitar mereka. ${ }^{4}$ Sehingga cara pandang di atas, melahirkan sebuah nilai spiritual dan nilai sosial yang dapat menjadi pedoman dalam kehidupan bersama. Nilai-nilai inilah yang mengajarkan masyarakat bahwa segala kejadian di alam semesta ini dapat dijadikan sebagai pelajaran bagi kehidupannya.

Sehubungan dengan tradisi, di Provinsi Jambi masih banyak tradisi-tradisi yang mengandung nilai spiritual dan falsafah hidup yang dilakukan oleh masyarakat, salah satunya menurut Rian Hidayat tradisi masyarakat Melayu Jambi yang mencerminkan nilainilai konservasi alam yang masih dipraktikan sampai saat ini, meski dalam skala yang relatif kecil, adalah tradisi baumo. Hingga saat ini tradisi baumo masih dikembangkan oleh sebagian kecil masyarakat pedesaan di beberapa kabupaten, seperti Kerinci, Bangko, Sarolangun, Bungo, Batanghari, Muaro Jambi, dan beberapa desa di Kabupaten Tanjung Jabung Barat dan Tanjung Jabung Timur. Hanya saja pengembangannya sudah menggunakan teknologi terkini, dan luasnya pun semakin hari semakin menurun seiring dengan pergeseran budaya pertanian dan desakan ekspansi perkebunan kelapa sawit dan Hutan Tanaman Industri (HTI). Ditinjau dari sisi sejarah perkembangan pertanian pangan, hampir semua masyarakat Jambi mulai dari wilayah barat, hingga pesisir pantai timur telah mengembangkan pertanian pangan dengan cara

3 Hardjasoemantri, Hukum dan Bencana Alam di Indonesia (Yogyakarta: Fakultas Hukum UII, 2013), 25.

${ }^{4}$ Hardjasoemantri, Hukum dan Bencana Alam di Indonesia, 27. 
tradisional yang dikenal dengan tradisi baumo itu. Pertanian tanaman pangan adalah kebutuhan hidup yang melintasi etnis, pesisir maupun pedalaman. ${ }^{5}$

Amat disayangkan, ketika tradisi baumo yang telah berlangsung secara turun temurun di masyarakat adat Melayu Jambi kini mulai tergeser eksistensinya oleh model pertanian modern berupa hutan tanaman industri yang paradigma pertaniannya adalah kemajuan demi kemajuan dengan sedikit mempertimbangkan faktor konservasi dan keseimbangan alam. Sedangkan pertanian tradisional seperti baumo selalu memiliki prinsip bertani dengan etika lingkungan dan kearifan lokal yang menjadi penopang dalam kelestarian lingkungan, keseimbangan alam dan manusia serta keseimbangan sosial. Ini yang menjadi permasalahan dari ekspansi pertanian modern terhadap budaya lokal. Ekspansi ini bukan hanya berakibat pada semakin sempitnya lahan untuk digunakan sebagai manifestasi tradisi baumo, tetapi juga berakibat pada tergerusnya nilai-nilai tradisi dan kearifan lokal dalam tradisi baumo itu sendiri.

Secara teoritis, seiring perkembangan zaman menurut Zulhakim, tradisi baumo mulai tergeser oleh budaya pertanian modern, yang juga mengakibatkan bergesernya nilai-nilai tradisional yang memiliki nilai kearifan lokal pada nilai-nilai. Ada beberapa faktor yang dapat menghambat bahkan menghilangkan tradisi baumo tersebut, salah satu diantarnya adalah adanya perkebunan kelapa sawit milik perusahaan yang menjadi faktor yang sangat dominan. ${ }^{6}$

Di samping permasalahan itu, ada keunikan tersendiri dari tradisi baumo yang menggabungkan antara keyakinan pada agama,

5 Rian Hidayat, Membangkitkan Batang Terendam (Jambi: Yayasan Setara, 2012), 53.

6 Pemprov Jambi, Laporan Status Lingkungan Hidup Daerah Provinsi Jambi Tahun 2014 (Jambi: Badan Lingkungan Hidup Daerah Provinsi Jambi Bidang Komunikasi dan Informasi Lingkungan dan Pemberdayaan Masyarakat, 2015), 14-17. 
kepercayaan pada mitos dan ketaatan masyarakat setempat pada hukum adat Melayu Jambi yang dipraktekan dalam tradisi baumo. Namun di dalamnya terkandung etika dalam kehidupan modern. Misalnya dapat ditelusuri dari seloko adat yang memandu masyarakat Kecamatan Batin XXIV dalam melakukan tradisi baumo, ada seloko adat yang berbunyi: "Laut sakti, rantau betuah, air bapuako, butan bepenunggu, di aik ado buayo putih, di butan ada bariman tangkis." Dalam kutipan seloko tersebut mengandung keyakinan pada mitos secara tersuratnya, namun kehidupan modern kini bisa dipahami sebagai etika lingkungan yang diajarkan dalam tradisi baumo. Itulah salah satu keunikan yang ada dalam tradisi baumo yang penting untuk diteliti.

Permaslahan dan keunikan dari eksistensi tradisi baumo tersebut, akhirnya menggugah minat penulis untuk meneliti tentang sisi nilai filosofis dan nilai spiritual yang terkandung dalam tradisi baumo masyarakat Melayu Jambi. Tradisi baumo sendiri merupakan salah satu warisan yang ada di masyarakat Kecamatan Batin XXIV yang seharusnya dipertahankan. Sebagai informasi awal tradisi baumo yang ada di masyarakat Kecamatan Batin XXIV diperkirakan luas lahan yang digunakan untuk baumo, sekitar 50-60 Ha kurang lebih dari setiap desa yang ada di Kecamatan Batin XXIV dengan luas wilayah kecamatan sekitar 89,813 Ha terbagi ke dalam 14 desa dan dua kelurahan dengan jumlah penduduk 25.418 jiwa. ${ }^{7}$ Inilah yang menjadi fokus dan objek penelitian dari tulisan ini, yaitu menggali dan memahami nilai filosofis dan nilai spiritual yang terkandung dalam tradisi baumo masyarakat Batin XXIV Batanghari. Untuk meneliti permasalahan itu, dapat dirumuskan dengan pertanyaan, "Bagaimana nilai filosofis dan nilai spiritual yang terkandung dalam tradisi baumo masyarakat Kecamatan Batin XXIV Kabupaten Batanghari?”

7 Rudi, Perangkat Kantor Kecamatan Batin XXIV, wawancara di Batanghari, tanggal 05 Mei 2019.

TAJDID vol. 19, No. 2, Juli - Desember $2020 \mid 193$ 
Untuk memahami dan menggali bagaimana nilai filosofis dan nilai spiritual yang terkandung dalam tradisi baumo masyarakat Kecamatan Batin XXIV Kabupaten Batanghari tersebut, penulis menggunakan satu teori utama dan dua teori pendukung. Teori utama dalam penelitian ini adalah teori wujud budaya milik Koentjaraningrat. Sedangkan teori pendukungnya adalah teori struktur filsafat dan teori nilai spiritual Notonegoro.

Dalam teori wujud kebudayaan menurut Koentjaraningrat, budaya memiliki tiga wujud, yaitu wujud abstrak budaya berupa ide-ide, gagasan dan nilai-nilai. Wujud fisik, aktifitas berpola dari budaya berupa tradisi yang dilestarikan dan wujud benda dan karya hasil budaya berupa bangunan-bangunan budaya, situs-situs budaya dan naskah-naskah budaya. ${ }^{8}$ Dalam pengaplikasiannya dalam penelitian ini, teori Koentjaraningrat bisa menjelaskan mengenai wujud abstrak dari tradisi baumo berupa nilai-nilai yang terkandung didalamnya dengan meneliti aktifitas berpola dari tradisi baumo tersebut dan menelaah naskah-naskah Melayu Jambi yang berkaitan dengan tradisi baumo.

Dalam teori struktur filsafat, sebagai pendukung teori utama, dijelaskan bahwa filsafat terdiri dari tiga unsur, yaitu ontologi, epistemologi dan aksiologi. ${ }^{9}$ Dengan epistemologi, penulis bisa menguraikan nilai-nilai dasar pengetahuan yang digunakan oleh masyarakat Batin XXIV dalam melakukan tradisi baumo, baik berupa pengetahuan yang berasal dari agama, mitos, hukum adat, maupun yang berasal pengalaman empiris. Sedangkan dari segi aksiologis, penulis bisa menggali nilai-nilai etika yang terkandung dan diterapkan oleh masyarakat Batin XXIV dalam melakukan tradisi baumo. Teori pendukung kedua adalah teori nilai spiritual milik Notonegoro yang menjelaskan bahwa nilai spiritual adalah nilai-nilai yang berasal dari sang maha pencipta yang nilai tersebut

8 Setiadi, Ilmu Sosial dan Budaya Dasar. (Jakarta: Kencana Prenada Media Group, 2017), 29.

9 Ali Maksum, Pengantar Filsafat dari Masa Klasik Hingga Postmodernisme, (Yogyakarta: Ar-Ruzz Media, 2016), 11. 
merupakan nilai tertinggi. ${ }^{10}$ Dalam penerapannya dalam penelitian ini, teori Notonegoro penulis gunakan untuk memahami nilai-nilai spiritual yang terkandung dalam tradisi baumo masyarakat Batin XXIV Batanghari.

\section{Pembahasan}

\section{Deskripsi Lokasi Penelitian}

Penelitian ini dilakukan Kecamatan Batin XXIV Kabupaten Batanghari berbatasan langsung dengan Kecamatan Muara Tembesi di sebelah utara dan timur dan di sebelah selatan berbatasan langsung dengan Kabupaten Sarolangun, sementara di sebelah barat berbatasan dengan Kecamatan Mersam dan Muaro Sebo Ulu. Kecamatan Batin XXIV terdiri dari 15 desa dan dua kelurahan, dengan ibukota kecamatan yang terletak di Kelurahan Muara Jangga, dengan jarak ke ibukota kabupaten 47 Km dan 107 Km ke ibukota Propinsi Jambi. Jumlah pendudukanya mencapai 27.291 jiwa.

Dari segi kehidupan sosial budaya masyarakat Kecamatan Batin XXIV, sebagaimana masyarakat secara umum, berangkat dari manusia sebagai makhluk sosial, manusia tidak bisa hidup tanpa bantuan dari manusia lain. Sehingga mengedepankan sikap tolong menolong dan saling bantu membantu. Begitulah yang terjadi dalam kehidupan masyarakat Kecamatan Batin XXIV. Selalu mengutamakan sikap kerjasama atau gotong royong ketika akan melakukan suatu acara yang mana acara tersebut melibatkan banyak pihak seperti aparat desa, tokoh masyarakat, karang taruna dan semua lapisan masyarakat.

Dari segi kehidupan agama yang merupakan keyakinan dan mempunyai peran penting bagi kehidupan. Karena dengan agama kehidupan masyarakat akan seimbang antara dunia dan akhirat. Dari beberapa hasil wawancara dengan tokoh agama dan

10 Agus. M. Hardjana, Religiositas, Agama dan Spiritualitas, (Yogyakarta: Kanisius, 2019), 64. 
masyarakat Kecamatan Batin XXIV didapat bahwa masyarakat Kecamatan Batin XXIV termasuk masyarakat yang religius dan menjunjung tinggi ajaran agama yang di anutnya yang tercermin dalam kehidupan meraka.

Dari segi pendidikan, dari hasil wawacara, dapat disimpulkan bahwa pendidikan merupakan kebutuhan dasar bagi masyarakat Kecamatan Batin XXIV meningkatkan pengetahuan yang dimilikinya. Maka, dalam rangka untuk memberikan kesempatan pada masyarakat menuntut ilmu, perlu didirikan berbagai macam sarana dan prasarana pendidikan formal maupun non-formal guna mengukur sejauh mana tinggi dan rendahnya kemajuan peradaban yang dimiliki oleh masyarakat setempat. Sehingga bisa dikatakan bahwa semakin banyak seseorang yang memiliki tingkat pendidikan tinggi, maka semakin banyak pula tingkat kepandaian yang dimiliki, begitu juga sebaliknya.

\section{Sejarah Baumo}

Baumo merupakan sebuah tradisi secara turun-temurun yang sudah ada dilakukan oleh masyarakat Kecamatan Batin XXIV dan umum masyarakat Provinsi Jambi sejak dulu. Ada sebagian masyarakat mengatakan tradisi baumo telah dilakukan jauh sebelum pemerintahan Belanda dan Jepang berkuasa di tanah Jambi. Masyarakat Kecamatan Batin XXIV sebelum mengenal budidaya tanaman karet, masyarakat hanya mengenal dan menanam tanaman bahan pokok (padi, sayur-sayuran) di lahan pertaniannya, selain kerja sampingnya mengambil hasil hutan sebagai mata pencariannya.

Wawancara dengan bapak Kasim, ia mengatakan sebelum masyarakat mengenal dengan budidaya berkebun karet, sawit terlebih dahulu masyarakat Kecamatan Batin XXIV sudah melakukan tradisi baumo hanya untuk menanam padi, jagung, ubi, sayuran dan segala macam tanaman untuk keperluan sehari, karena pada masa itu tidak ada orang yang menjual kebutuhan pokok dan 
sayur-sayuran. Jadi, masa dahulu apabila tidak baumo sangat susah untuk memenuhi kebutuhan pokoknya sehari-hari. Karena menanam padi, jagung, cabe dan lain-lainnya. Tetapi, apabila baumo payo, masyarakatnya bisa menanam padi saja. Jadi, dengan baumo masyarakat tidak kekurangan untuk kebutuhan pokoknya."

Dari hasil wawancara di atas dapat disimpulkan bahwa pada prinsipnya baumo di Kecamatan Batin XXIV sebagai upaya masyarakat untuk memenuhi kebutuhan, karena terlihat dari semua jenis tanaman yang ditanam di lahan umo pada masa itu merupakan tanaman pokok. Sejak dulu hampir rata-rata masyarakat Kecamatan Batin XXIV berprofesi baumo, karena baumo merupakan pekerjaan masyarakat yang tidak membutuhkan modal dalam bentuk uang, tetapi banyak menggunakan tenaga, karena umumnya semua proses pertanian baumo dilakukan masyarakat secara bergotong-royong.

Kemudian menurut bapak Kasim, umo juga terdiri dari berbagai jenis di antaranya: pertama, umo renah adalah berupa dataran rendah yang dijadikan sebagai lahan tempat menanam padi dan tanaman pangan lainnya. Kedua, umo kasang, berupa dataran tinggi yang dijadikan sebagai lahan tempat menanam padi dan kebutuhan pangan lainnya. Ketiga, umo payo, merupakan dataran rendah yang berair, dijadikan sebagai tempat menaman padi dan sayuran daun berumur pendek seperti kangkung, juga menjadi areal ternak itik, umumnya setiap paska musim panen, petani melepaskan ternak itiknya di umo payo. Saat ini umo payo ini disebut dengan istilah sawah. ${ }^{11}$

\section{Proses Baumo Masyarakat}

Melihat proses baumo yang dilakukan oleh masyarakat Kecamatan Batin XXIV terdapat beberapa proses yang harus dilakukan jika masyarakat ingin membuka lahan umo. Adapun

\footnotetext{
${ }^{11}$ Kasim, Petani Umo, wawancara di Batanghari, tanggal 02 Juli 2020.
} 
tahapan dan proses baumo yang dilakukan masyarakat Kecamatan Batin XXIV di antaranya adalah sebagai berikut:

1. Pembukaan Lahan (Penambangan dan Penebasan)

Pembukaan lahan disebut dengan tahap penebangan dan penebasan yang bertujuan untuk membersihkan hutan dari pohon besar dan pohon kecil, sehingga menjadi sebuah lahan pertanian. Kemudian adapun proses membukan lahan umo di Kecamatan Batin XXIV banyak menggunakan alat-alat tradisonal dan sederhana seperti parang, gergaji besar, kapak, beliung kayu dan peralatan tradisional lainnya untuk menebang kayu besar.

Kemudian untuk memastikan bagaimana proses masyarakat membuka lahan untuk baumo di Kecamatan Batin XXIV, sudah dilakukan wawancara dengan beberapa petani umo. Adapun proses pertama kali yang dilakukan masyarakat baumo adalah membuka lahan yang telah ditentukan sebelumnya. Membukan lahan dengan cara menebang kayu. Jika lahan baumo berada di daerah perbukitan, maka kayu yang paling dahulu ditebang adalah pohon kayu yang berada paling bawah bukit, dengan cara menebang pohon kayu yang ada di bawah namun tidak sampai tumbang, karena kayu yang di bawah nanti akan ditimpa kayu yang sudah ditebang di atasnya. Cara dan strategi membukan lahan menebang kayu seperti itu, akan lebih mempercepat dan mempermudahkan sedikit dari perkerjaan mereka. Staregi membukan lahan seperti sudah diajarkan oleh nenek moyang mereka terdahulu secara turun temurun.

Berdasarkan hasil wawancara di atas, dapat disimpulkan bahwa alat yang paling banyak digunakan oleh masyarakat Kecamatan Batin XXIV untuk membukan lahan umo yaitu beliung dan parang, kemudian juga dapat dikatakan bahwa dulu untuk membuka lahan hanya mengandalkan kemampuan dan tenaga manusia. Selain itu, dalam membukan lahan umo 
masyarakat selalu mengedepan sikap saling membantu atau disebut dengan—oleh masyarakat— "nyerayo". Gotong royong (nyerayo) selalu dilakukan oleh masyarakat yang baumo. Artinya kepedulian masyarakat Kecamatan Batin XXIV terhadap sesamanya dan lingkungan yang disebut dengan saling membantu, saling berbagi dan saling percaya juga tercermin dalam beberapa proses kegiatan baumo tersebut.

2. Penyincangan

Proses penyincangan kayu dan ranting pohon yang sudah ditebang di dalam lahan umo merupakan suatu proses yang harus dilakukan dalam rangkan untuk memudahkan proses pengeringan dan pembakarannya nanti, karena dengan ada penyincangan kayu dan ranting tersebut membuat kayu lebih cepat kering dan api lebih mudah membakarnya bila dibakar. Menurut hasil wawacara dengan bapak M. Zaidi, ia mengatakan bahwa penyincangan kayu dan ranting yang disebut masyarakat petani umo Kecamatan Batin XXIV "selaro kayu”. Penyincangan selaro kayu merupakan hal yang penting harus dilakukan secara baik setelah proses penebangan, kemudian penyincangan selaro kayu yang sudah ditebang sangat berdampak pada penentukan hasil dari pembakaran lahan nanti. Bila penyincangannya bagus, pengeringan kayu juga menjadi cepat dan kayu yang ditebang bisa cepat kering dan bila dibakar kayu semuanya mudah terbakar, yang secara otomatis berdampak kepada kesuburan tanah lahan nantinya.

3. Pengeringan

Proses ini adalah proses lanjutan setelah penyincangan selaro. Pengeringan dilakukan bertujuan untuk mengurangi kadar air dari pohon yang sudah ditebang menunggu sampai kering supaya mudah untuk dibakar, sehingga proses pembakaran dapat berjalan dengan cepat. Adapun proses pengeringan ini dari hasil penyincangan dibiarkan 15-30 hari di 
bawah terik matahari sebagai proses pengeringan, ini juga tergantung pada petani itu sendiri. Apabila baumo di musim panas, maka pohon dan kayu lebih cepat kering, dan apabila di musim hujan mungkin petani lebih lama menunggu proses pengeringan. Pada masa proses pengeringan ini, petani tidak melakukan apa-apa terhadap pohon dan selaro kayu yang sudah di tebang tadi, petani hanya menunggu pohon dan selaro kering saja, sampai pada waktu yang tepat untuk proses pembakaran.

4. Pembuatan Sekat

Proses pembuat sekat dilakukan setelah pengeringan dan sebelum pembakaran lahan. Pembuatan sekat-sekat yaitu membersihkan di sekeliling lahan umo dari pohon dan selaro kayu kering, biasanya sekat yang dibuat oleh petani umo di Kecamatan Batin XXIV selebar dua meter dan ada juga beberapa petani membuat sekat bakar agak lebih lebar tiga sampai empat meter, tetapi pada umumnya petani hanya membuat dua meter. Setelah membuat sekat kemudian baru dibersihkan dan dipastikan tidak ada daun, pohon dan selaro kayu kering yang mudah terbakar yang terdapat di atas sekat, setelah itu baru sekat-sekat yang sudah dibuat disiram dengan air supaya basah, sekat ini harus dibuat oleh petani supaya dalam proses pembakaran lahannya nanti tidak terjadi perembatan api kelahan umo yang berada di sebelah atau kebun-kebun yang berada di sekelilingnya. Kemudian pembuatan sekat ini, tidak harus dilakukan setiap petani umo, karena sekat hanya berfungsi untuk menghidari perembatan api saja apa proses pembakaran nanti. Jadi, pembuatn sekat hanya melihat situasi dan kondisi lahan apa saja yang ada berbatasan dengan lahan umo kita yang akan dibakar. Jika lahan umo kita banyak berbatasan dengan kebun milik orang lain, maka sekat diperlukan. Tetapi, jika berbatasan dengan hutan primer atau hutan belantara atau sesama lahan umo, maka sekat tidak perlu dilakukan. 
5. Pembakaran

Pembakaran merupakan suatu proses yang dilakukan masyarakat Kecamatan Batin XXIV untuk mengubah hutan menjadi lahan pertanian. Sebelum pembakaran lahan biasanya petani umo menentukan arah angin, karena petani beranggapan bahwa angin dapat mempercepat proses pembakaran nantinya. Hasil wawancara menurut bapak M. Habibi selaku petani umo desa Pakuaji bahwa sebelum membakar lahan biasanya masyarakat harus menentukan arah angin supaya proses pembakarannya bagus. Adapun cara menentukan arah angin masyarakat cukup melihat gerak daun dan pohon yang berlum ditebang yang berada di samping lahan umo yang akan dibakar. ${ }^{12}$ Setelah itu baru dilanjutkan dengan proses pembakaran lahan. Kemudian menurut Bapak Azra'i, ia mengatakan bahwa aktivitas pembakaran ini disebut dengan istilah "manggang" ada sebagian lain menyebutnya "merun", pembakaran lahan ini bertujuan untuk menyuburkan tanah, setelah itu baru dilakukan penanaman padi, dengan cara tanjak untuk umo kasang, dan nandur untuk umo kasang. ${ }^{13}$

Selanjutnya menurut Ade Kusnadi, ia mengatakan bahwa biasanya terdapat dua teknik sistem pembakaran lahan ladang yang dilakukan oleh masyarakat yaitu: (1) Teknik pembakaran melingkar (ring firing) dan (2) Teknik pembakaran muka (head firing) dan sistem pembakaran balik (backfiring). ${ }^{14}$ Menurut hasil wawancara dengan Bapak Madri Hasan selaku petani umo di Desa Matagual mengatakan bahwa proses pembakaran lahan umo yang dilakukan masyarakat di Kecamatan Batin XXIV dengan menggunakan sistem kepung

\footnotetext{
${ }^{12}$ M. Habibi, Petani Umo, wawancara di Batanghari, tanggal, 02 Juli 2020

13 Datuk Azra'I, Ketua Lembaga Adat Kota Jambi, wawancara di Jambi, tanggal 14 Juli 2020.

14 Ade Kuswandi, “Teknik Pembakaran Lahan Dalam Penyiapan Ladang Berpindah Dari Kawasan HTI PT. Finnatara Intiga Resor Entanjan Kab. Sanggau-Kalimantan”. Skripsi IPB (2016), 41.
} 
atau sistem pintas, pembakaran dimulai dari titik permukaan umo yang paling rendah. Proses pembakaran seperti ini adalah kebiasaan (culture) masyarakat secara turun menurun yang sudah mereka lakukan sejak dulu, karena melihat tipologi geografi lahan yang berbukit dan lurah. Tetapi jika areal umo relatif datar, biasanya proses pembakarannya menggunakan sistem keliling atau melingkar, supaya api menjalar ketengah lahan dari semua penjuru.

6. Penentuan Hari Baik

Selain dari beberapa tahap pembukaan lahan umo di atas, ada pula proses menentukan hari baik sebagai permulaan penanaman padi di lahan umo. Dalam kepercayaan masyarakat Kecamatan Batin XXIV siapa saja petani mengikuti dan melaksanakan penentuan hari baik tersebut, maka akan terhindar dari hal-hal yang buruk dan juga sebagai wujud ketaatan pada Allah.

Menurut Datuk Azra'i selaku Ketua Balai Adat Kota Jambi, tradisi penentuan hari baik itu, dilaksanakan dengan merujuk pada ajaran Islam, yaitu dengan memilih bulan-bulan khusus atau mempertimbangkan keutamaan-keutamaan pada bulan-bulan di tahun Hijriyah sebagai awal untuk menanam padi umo. Seperti bulan Safar sebagai bulan bala dalam pemahaman orang tua dulu atau bulan Syawal, Dzul Qa'dah, Muharram dan Rabiul Awal yang pada bulan tersebut terdapat keutamaan-keutamaan. Oleh karenanya, pada bulan-bulan tersebut, petani biasanya memulai untuk menyemai benih, dan jika kebetulan baumo di bulan Safar, maka dalam pengerjaannya harus hati-hati, karena bulan safar dianggap bulan bala. Kemudian pemilihan hari baik ini dikaitkan dengan keutamaan-keutamaan dan pantangan yang ada pada bulanbulan di tahun Hijriyah, seperti Safar adalah bulan kedua dalam penanggalan Islam setelah bulan Muharram. Namun, ketika berbicara tentang Safar, tidak sedikit orang tua dulu 
yang baumo, masih memiliki pemikiran bahwa terdapat kesialan pada Safar.

Sedangkan bulan Muharram dan bulan Dzul Qa'dah sendiri merupakan dua dari empat bulan yang mulia. Bulan mulia lainnya adalah Dzul Hijjah dan Rajab. Di bulan-bulan tersebut manusia dilarang menzalimi diri sendiri dan melalukan perbuatan dosa. Rasulullah saw. menyebut bulan Muharram sebagai Syahrullah (bulan Allah). Termasuk dianjurkan menjalani puasa Muharram. Oleh karena itu, pada dua bulan tersebut para petani dianjurkan untuk baumo. Begitu pula pada bulan Rabi'ul Awal, yang merupakan bulan ketika Nabi dilahirkan. ${ }^{15}$

\section{Proses Ritual Kayo Aro}

Setelah menentukan hari baik, maka akan diadakan ritual kayu aro sebelum menanam padi. Tradisi kayu aro merupakan salah satu tahapan dalam baumo, tepatnya ketika petani umo akan memulai menanam padi. Tradisi kayu aro dimulai dengan mempersiapkan ramuan-ramuan dan beragam jenis makanan serta kayu aro yang akan ditancapkan di tengahtengah umo yang akan ditanami dan disusun sedemikian rupa sehingga membentuk seperti panjat pinang.

Uraian di atas, dikuatkan dengan hasil wawancara dengan Bapak Sukarni, ia mengatakan untuk menentukan hari partama menanam padi disebut dengan nugal, juga terdapat sebuah proses ritual khusus yang disebut dengan ritual "kayu aro", dimana kayu ditancapkan di tengah umo, lalu di ujung kayu tersebut digantungkan beragam makanan dan kain panjang (seperti tradisi panjat pinang), lalu kayu tersebut di panjat oleh "Ulu Balang", dan makanan dilemparkan ke para petani yang sudah berkumpul di tengah umo, itu menandakan

15 Datuk Azra'I, Ketua Lembaga Adat Kota Jambi, wawancara di Jambi, tanggal 14 Juli 2020. 
penanaman padi akan segera dimulai. Padi pertama ditanam di mana ulu balang pertama kali menancapkan kayu aro, di situlah padi pertama ditanam. ${ }^{16}$

\section{Mempertahankan Tradisi Baumo}

Tradisi baumo di Kecamatan Batin XXIV sampai saat ini masih tetap dipertahakan masyarakat walaupun tidak banyak seperti dulu lagi, adapun masyarakat yang mempertahankan tradisi tersebut, karena di dalam tradisi baumo tidak hanya semata-mata untuk memenuhi kebutuhan pangan masyarakat saja, tetapi juga bagian dari pelestarikan nilai-nilai moral dan norma religius yang bernilai tinggi dan filosofis yang terkandung dalam sebuah ritual tradisi baumo. Nilai-nilai itulah sejak dulu terbukti telah menyatu dalam kehidupan masyarakat Kecamatan Batin XXIV, selain itu dengan nilai-nilai ini jugalah membuat hubungan yang harmonis antara masyarakat dengan alam sekitarnya. Tradisi baumo di masyarakat Kecamatan Batin XXIV tersebut sudah ada sejak dahulu mulai dari nenek moyang mereka. Sehingga tradisi baumo ini adalah sebagai sebuah mata pencarian warisan secara turun temurun yang mengandung nilai-nilai moral yang harus dilestarikan oleh masyarakat Kecamatan Batin XXIV.

Kemudian seiring dengan perkembangan zaman saat ini, jumlah petani umo di Kecamatan Batin XXIV mulai berkurang dari tahun ketahun dan akses masyarakat untuk baumo tersebut juga mulai semakin kecil seiring dengan masifnya perluasan tanaman industri, perkebunan sawit dan karet dengan skala besar, hingga tambang batu bara. Penyebab lain, adanya pula gaya hidup masyarakat yang materialis dan individualis turut menambah melemahnya semangat masyarakat untuk melakukan tradisi baumo di Kecamatan Batin XXIV. 2020 .

${ }^{16}$ Sukarni, Selaku Petani Umo, wawancara di Batanghari, tanggal 02 Juli 
Sehingga untuk mempertahankan tradisi baumo di Kecamatan Batin XXIV, menurut bapak kasim, sebaiknya tradisi baumo ini tidak boleh hilang di masyarakat kita baik umo renah, umo kasang maupun umo payo. Supaya tradisi ini tetap terjaga dan berkembang, diharapkan kepada para tokoh agama, tokoh masyarakat, dan struktur desa serta ketua pemuda untuk membuat sebuah kegiatan dalam rangka mensosialisasikan nilai-nilai agama, nilai-nilai budaya dan adat-istiadat yang terkadung dalam tradisi baumo kepada generasi selanjutnya.

Menurut Zuwardi untuk meneruskan tradisi baumo di Kecamatan Batin XXIV, ia mengatakan: pertama, petani umo harus bisa memberikan contoh dan harapan kepada masyarakat lain bahwa hasil umo yang dia dapat memenuhi kebutuhan keluarganya dan dapat meningkatkan perekonomiannya. Kedua, petani umo harus menerapkan nilai-nilai yang terkadung dalam tradisi baumo dalam kehidupan bermasyarakat, seperti ikut bergotong royong dan selalu ikut dalam kegiatan-kegiatan sosial lainnya. Ketiga, petani umo harus menceritakan bahwa baumo itu tidak hanya semata-mata sebagai mata pencarian untuk memenuhi kebutuhan saja, tetapi juga sebagai upaya pelestarian nilai-nilai moral yang telah diwariskan secara turun temurun. ${ }^{17}$

Selanjutnya, menurut Erwin, sebagai camat Kecamatan Batin XXIV, ia mengatakan bahwa untuk meningkatkan minat dan semangat masyarakat dalam mengembangkan tradisi baumo di Kecamatan Batin XXIV, ia mengharapkan peran pemerintah, baik pemerintah pusat, pemerintah provinsi terutama pemerintah Kabupaten Batanghari harus membuat sebuah program untuk menjadikan Kecamatan Batin XXIV sebagai wilayah swasembada padi umo, baik umo renah, umo kasang maupun umo payo di Kabupaten Batanghari dan program ini juga harus tidak sedikitpun meninggalkan proses-proses ritual di dalamnya. Jika program swasembada padi umo ini dilakukan dan petani mengikuti program

${ }_{17}$ Zuwardi, Selaku Petani Umo, wawancara di Jambi, tanggal 02 Juli 2020.

TAJDID vol. 19, No. 2, Juli - Desember 2020 | 205 
tersebut mendapatkan hasil yang memuaskan, sehingga secara otomatis masyarakat akan banyak mengikuti program tersebut dan secara tidak langsung pula tradisi baumo dan nilai-nilai di dalamnya dapat berkembang lagi dan dapat pula diimplementasikan dalam kehidupan bermasyarakat di Kecamatan Batin XXIV. ${ }^{18}$ Selanjutnya, menurut Adi selaku kepala Desa Karmeo, adapun salah satu upaya yang harus dilakukan para petani umo untuk melestarikan nilai-nilai dalam tradisi baumo tersebut adalah dengan melakukan sistem pewarisan dini yang utuh dan berkesinambungan yaitu dengan cara mengajak anak, istri dan keluarga atau generasi muda dilingkungannya untuk turun ke umo terutama ketika menanam dan memanen padi umo yang sudah dibuatnya. Dengan diajaknya generasi muda terlibat dalam proses menanam dan memanen, diharapan bisa membangun semangat untuk melakukannya. ${ }^{19}$

Beberapa pendapat dari hasil wawancara di atas, dapat disimpulkan bahwa semua responden mengatakan bahwa menumbuhkan dan melestarikan tradisi baumo Kecamatan Batin XXIV sangatlah penting untuk meningkatkan kecintaan masyarakat setempat terhadap budaya lokal yang mereka miliki. Berkembang atau tidaknya tradisi baumo tersebut tergantung pada bagaimana menjelaskan dan mensosialisasi tentang pentingnya nilai-nilai yang terkandung dalam tradisi tersebut dari generasi ke generasi, sehingga tidak terputus. Tradisi baumo merupakan sebuah amanah untuk selalu dikembangkan dan ditanamkan para orang tua kepada anak-anaknya dan generasi di bawahnya. Kemudian peran pemerintah daerah setempat untuk melestarikan tradisi baumo dan menjadikan Kecamatan Batin XXIV, sebagai wilayah swasembada padi umo, yang nantinya akan dapat meningkatkan taraf hidup masyarakat setempat.

${ }^{18}$ Erwin, Camat Batin XXIV Batanghari, wawancara di Batanghari, tanggal 02 Juli 2020.

19 Zuwardi, Selaku Petani Umo, wawancara di Batanghari, tanggal 02 Juli 2020.

206 | TAJDID vol. 19, No. 2, Juli - Desember 2020 


\section{Nilai Filosofis Tradisi Baumo}

\section{Aspek Epistemologi}

a. Adat dan Tradisi

Tradisi baumo masyarakat Batin XXIV, selalu harus berpedoman pada adat-istiadat yang telah diwariskan secara turun temurun yang tertuang dalam lembaga adat dan tidak boleh melanggar adat yang telah diatur oleh syarak. Masyarakat Batin XXIV juga selalu berpedoman pada ajaran Islam "Adat bersandi syarak, syarak bersandi kitabullah." Kalimat ini menunjukan bahwa kebiasaan yang ada di tengah masyarakah masyarakat Batin XXIV senantiasa berpedoman pada nilai-nilai agama Islam. Tetapi ada juga sebagaian masyarakat masih menganut kepercayaan gaib yang berselubung mistis, karena masih beranggapan ada kekuatan sakti yang sewaktu-waktu dapat menimbulkan malapetaka bagi seseorang yang menentang aturan adat yang sudah ditentukan. ${ }^{20}$

b. Dasar Pengetahuan Empiris

Pengetahuan masyarakat Batin XXIV tentang gejalagejala alam yang dijadikan pemandu di dalam baumo terutama pengetahuan tentang musim-musim, tentang bintang dan sebagainya. Pengetahuan tersebut sesungguhnya berasal dari kebutuhan-kebutuhan praktis untuk baumo, baik baumo di umo maupun di ladang. Perhitungan ini sesuai dengan ilmu perbintangan dan tidak semua penduduk mengetahuinya, yang mengetahui perhitungan ini biasanya adalah ulama, atau tuo-tuo tengganai di desa. Contoh lain Saat bintang timur muncul di langit dengan warna yang lebih tajam dan bintang tujuh yang

20 Eva Zulfita dkk, Kearifan Tradisional Masyarakat Pedesaan dalam Pemeliharaan Lingkungan Hidup di Daerah Provinsi Jambi, (Jakarta: Departemen Pendidikan dan Kebudayaan, 2013), 93. 
mengelompok itu terletak di sisi bumi di sebelah barat, maka keadaan tersebut menandai awal musim panas dan orang-orang mulai bersiap untuk pergi ke ladang untuk menebang semak-semak, menebang dan mengubur ke tanah, semak-semak ditebang dan dibakar. ${ }^{21}$

\section{Aspek Aksiologis (Etika)}

a. Etika Lingkungan

Masyarakat Batin XXIV juga mengetahui bahwa Tuhan menciptakan alam untuk kepentingan sebagai manusia. Manusia adalah yang paling mulia dari semua makhluk, yang dipercayakan untuk mengelola alam ini untuk kebutuhannya. Di sinilah letaknya hakekat nasehat yang terkandung di dalam ungkapan di atas. Seperti yang dikatakan Datuk Azra'i, "Jika ke butan jangan mengusike binatang, jangan lasak, jangan netak-netakkan parang sembarangan, jangan takabru, jika berjalan bertemu dengan patahan ranting yang menghalangi perjalanan maka ambillah ranting tersebut dan dibuang, jikea bertemu ular, mengbindarlah jangan terkejut dan jangan memekik."

Hal ini juga sesuai dengan seloko adat:

"Laut sakti, rantau betuah,

Aik bapuako, butan bepenunggu,

Di aik ado buayo putih,

Di butan ado harimau tingkis. ${ }^{, 22}$

b. Etika Hidup

Dalam tradisi baumo, masyarakat Batin XXIV juga mengenal seloko berikut yang mengajarkan tentang kearifan dalam menjalanai kehidupan:

"Elok secanting asal berenas daripado segantang nampo berat, 2020.

${ }^{21}$ Bapak Kasim, Petani Umo, wawancara di Batanghari, tanggal 02 Juli 22 Zulfita dkk, Kearifan Tradisional, ... 61. 
Baumo sabidang dapat berzakat,

Dua bidang cukup untuk makan,

Tigo bidang menuai padi hampo."23

Jadi, sekuat apapun tenaga yang dimiliki seseorang untuk membuka lahan umo tentu tetap dibatasi oleh kemampuan dan waktu, jadi lahan yang mampu mereka buka lahan umo umumnya sesuai dengan kesediaan tenaga yang dimiliki oleh keluarga, dan tanaman yang diproduksi pun berimbang dengan kebutuhan masing-masing keluarga.

\section{Nilai Spiritual Tradisi Baumo}

\section{Etika terhadap Padi (Keyakinan Pada Adanya Jiwa Padi)}

Dalam tradisi baumo masyarakat Batin XXIV ada tradisi penyiapan benih hingga selamatan padi baru, dalam rangkaian tradisi tersebut terkandung kepercayaan terhadap adanya jiwa pada padi umo tersebut dan kepercayaan terhadap ajaran Islam. Seperti pada prosesi penyiapan benih. Sebelum ditanam, bibit padi terlebih dahulu dimandikan dengan air yasin. ${ }^{24}$

\section{Pemilik Hari Baik}

Dalam menghitung tanggal untuk baumo pada umumnya masyarakat Batin XXIV menggunakan tanggal dan nama bulan Arab yaitu Muharram, Safar, Rabiul Awal, Rabiul Akhir, Jumadil Awal, Jumadil Akhir, Rajab, Sa'ban, Ramadhan, Syawal, Dzul Qa'dah dan Dzul Hijjah. Biasanya untuk menentukan tanggal berapa sekarang mereka berpedoman pada bentuk bulan di langit, jika bulan berbentuk "bulan sabit", berarti pada waktu itu tanggal di bawah tanggal sepuluh, jika bulan tersebut berbentuk "bulan penuh", berarti pada saat itu waktu sudah memasuki pertengahan bulan, dan

${ }^{23}$ Zulfita dkk, Kearifan Tradisional, ... 48.

${ }^{24}$ Datuk Azra’i, Ketua Lembaga Adat Kota Jambi, wawancara pada tanggal 14 Juli 2020. 
apabila bulan sudah tidak kelihatan lagi berarti saat itu sudah mulai memasuki pergantian bulan berikutnya. ${ }^{25}$

\section{Selamat Padi Baru: Basokat sebagai Wujud Kepercayaan terhadap Agama}

Selain itu, sebagai seorang muslim petani umo di Kecamatan Batin XXIV juga mengeluarkan zakat mal yaitu berupa padi itu sendiri. menurut aturan adat-istiadat bagian dari sebuah sikap saling berbagi antara sesama masyarakat, zakat yang dikeluarkan untuk setiap ladang yang dimiliki petani adalah sebesar $10 \%$ dari total hasil panen. ${ }^{26}$

\section{Menyapo Padi sebagai Wujud Kepercayaan Pada Jiwa Padi}

Menyapo padi, yaitu menyapa padi dengan mengucapkan assala mu'alaikum warabmatullabi wabarakatuh, sambil memegang daun padi yang sudah dipilih untuk menjadi bibit. Menurut kepercayaan masyarakat Batin XXIV bahwa padi mempunyai jiwa, kalau tidak punya jiwa mana bisa dia tumbuh, menghijau, berumput, berbuah lalu menguning. ${ }^{27}$

\section{Penutup}

Hasil penelitian ini terdapat sebuah kesimpulan umum bahwa mengembang dan melestarikan tradisi baumo Kecamatan Batin XXIV sangatlah penting sebagai upaya untuk meningkatkan kecintaan masyarakat setempat terhadap budaya lokal yang mereka miliki. Tradisi baumo tidak semata-mata hanya sebagai mata pencarian untuk memenuhi kebutuhan masyarakat saja, tetapi juga bagian dari pelestarian nilai-nilai yang terkadung dalam proses

${ }^{25}$ Datuk Azra’i, Ketua Lembaga Adat Kota Jambi, wawancara pada tanggal 14 Juli 2020.

${ }^{26}$ Datuk Nur, Ketua Lembaga Adat Kecamatan Batin XXIV, wawancara pada tanggal 09 Juli 2020.

27 Datuk Nur, Ketua Lembaga Adat Kecamatan Batin XXIV, wawancara pada tanggal 09 Juli 2020. 
ritual baumo. Kemudian sebagai upaya untuk menguatkan temuan umum penelitian di atas, berikut ini temuan-temuan yang lebih spesifik yang menjadi jawaban dari pertanyaan penelitian. Pertama, nilai filosofis yang terkandung dalam tradisi baumo dapat dilihat dari dua sisi, yaitu epistimologis dan aksiologis. Secara epistemologis, pengetahuan dan praktek masyarakat dalam melaksanakan tradisi baumo didasarkan pada pengetahuan dan pengalaman empiris masyarakat tentang musim-musim, cuaca, gejala alam, ilmu perbintangan dan pengalaman empiris lain yang berkaitan dengan prosesi tradisi baumo. Pengetahuan masyarakat tentang tradisi baumo juga didasarkan pada pengetahuan dan ketaatan masyarakat terhadap hukum adat, yaitu hukum adat Jambi yang bersandi syarak, syarak yang bersandi kitabullah. Selain itu, praktek tradisi baumo juga didasarkan pada pengetahuan masyarakat Batin XXIV tentang tentang pengalaman mistis, mitos-mitos yang diyakini dan pantangan-pantangan yang dianut oleh masyarakat setempat. Secara aksiologis, yaitu yang berkaitan dengan etika, logika dan estetika. Dari naskah-naskah seloko adat dan praktek tradisi baumo yang dilakukan oleh masyarakat Batin XXIV dapat dilihat bahwa masyarakat setempat memegang prinsip etika lingkungan dalam melakukan taradisi baumo, yaitu kearifan lokal tentang konservasi alam dan menjaga keseimbangan alam dan manusia. Selain etika lingkungan, masyarakat juga memegang prinsip etika hidup, yaitu etika hidup sederhana, secukupnya, namun tetap peduli secara sosial pada lingkungan masyarakat.

Kedua, nilai spiritual yang terkandung dalam tradisi baumo dapat terlihat dari beberapa prosesi tradisi baumo yang dilakukan oleh masyarakat Batin XXIV yang banyak dipengaruhi oleh ajaran Islam dan mitos-mitos yang bercorak animisme. Nilai-nilai spiritual dalam tradisi baumo antara lain adalah keyakinan pada jiwa padi. Hal ini terlihat dari prosesi tradisi baumo yang diawali dengan proses memandikan benih diiringi dengan membaca basmalah dan menyiramkan air yasin, lalu digendong dan disemai. Begitu pun dalam proses pengelolaan lahan umo ada ritual menyapo padi dengan 
sapaan seperti pada manusia, harus memperlakukan padi sebagaimana memperlakukan anak, dimandikan dengan air yasin, disapo dan disayangi dengan kesantunan dan adab-adab. Nilai spiritual tentang keberkahan juga dapat dilihat dari ritual penentuan hari baik saat akan memulai tradisi baumo. Ritual penentuan hari baik ini di-ilhami oleh keyakinan masyarakat setempat mengenai keberkahan yang ada pada bulan-bulan Hijriyah, juga keutamaan-keutamaan dan pantangan-pantangan yang ada di dalamnya. Nilai spiritual dalam tradisi baumo juga berbentuk rasa syukur pada alam dan manusia. Selamatan padi baru merupakan satu bentuk rasa syukur pada alam. Ritual ini dilakukan dengan menyapo padi dan berbagi dengan lingkungan saat basokat, serta memperlakukan pada sebagai mahluk yang berjiwa.

\section{Daftar Pustaka}

Al-Qur'an dan Terjemahannya, Departemen Agama RI. Jakarta: Depag Republik Indonesia 2018.

Hardjana, Agus M. Religiositas, Agama danSpiritualitas. Yogyakarta:Kanisius, 2019.

Hardjasoemantri. 2003 Hukum dan Bencana Alam di Indonesia. Yogyakarta: Fakultas Hukum UII, 2013.

Hidayat, Rian. Membangkitkan Batang Terendam. Jambi: Yayasan Setara, 2012.

Kuswandi, Ade. “Teknik Pembakaran Lahan Dalam Penyiapan Ladang Berpindah Dari Kawasan HTI PT. Finnatara Intiga Resor Entanjan Kab. Sanggau-Kalimantan”. Skripsi IPB, 2016.

Maksum, Ali. Pengantar Filsafat dari Masa Klasik Hingga Postmodernisme, Yogyakarta: Ar-Ruzz Media, 2016.

Pemprov Jambi, Laporan Status Lingkungan Hidup Daerah Provinsi Jambi Tahun 2014 Jambi: Badan Lingkungan Hidup Daerah Provinsi Jambi Bidang Komunikasi dan Informasi Lingkungan dan Pemberdayaan Masyarakat, 2015 
Setiadi. Ilmu Sosial dan Budaya Dasar. Jakarta: Kencana Prenada Media Group, 2017.

Syam, Nur. Islam pesisir. Yogjakarta: Lkis Pelangi Aksara, 2015.

Zulfita, Eva dkk. Kearifan Tradisional Masyarakat Pedesaan dalam Pemeliharaan Lingkungan Hidup di Daerah Provinsi Jambi, Jakarta: Departemen Pendidikan dan Kebudayaan, 2013. 